\title{
Exploring the Factors Responsible for Declining Students' Interest in Chemistry
}

\author{
Tayyaba M. Akram, Ayesha Ijaz, and Hamid Ikram
}

\begin{abstract}
The present study aimed to explore the factors responsible for declining students' interest towards chemistry. In this casual comparative study, the researchers collected data, through a questionnaire, from 600 science students of different secondary schools of government, semi-government, and private sectors of Lahore, Pakistan. The data analysis included mean, standard deviation (SD), percentages, correlation, t-test, and ANOVA. The results showed that students had less interest in chemistry, and the problem is more pronounced in $10^{\text {th }}$ grade students. The most prominent area of students' interest was chemistry experiments. The students in public schools were more interested in chemistry courses as compared to their peers enrolled in private schools. Moreover, the researchers found that older students were less interested in chemistry courses as compared to younger students. Among major factors, Personal Traits and Choices showed distinct role in developing students' interest towards chemistry, while Professional Scope and Role of Teacher declined students' interest. However, awareness and interest about The Professional Scope of Chemistry courses may be developed through seminars and career counselling. Also, teachers should have trainings in teaching chemistry courses to develop students' interest.
\end{abstract}

Index Terms-Declining interest in chemistry, personal traits and choices, professional scope, role of teacher.

\section{INTRODUCTION}

Interest is a key factor in the field of science education [1]. From the last two decades of $20^{\text {th }}$ century, the concept of interest gained new blood in science educational societies [2], [1]. Program for International Student Assessment [3], in its framework, has recognized the concept of interest as an important component of scientific literacy [3]. In Pakistan, the aim to develop students' interest is a part of curriculum documents with a great emphasis (National Curriculum of Chemistry at $9^{\text {th }}$ and $10^{\text {th }}$ grades, Ministry of Education, 2006).

In literature related to education and psychology, the term interest has been defined by several researchers [4], [5]. According to Hidi, interest is a unique "psychological state that occurs during interactions between persons and their objects of interest" [4]. The similar view is given by the educational theory of interest known as person-object theory of interest. According to this theory, "interests evolve out of manifold relationships between persons and objects in social and institutional settings. An interest represents a specific and distinguished relationship between a person and an object. An

Manuscript received August 29, 2015; revised December 2, 2015.

T. M. Akram and A. Ijaz are with the University of the Punjab, Pakistan (e-mail: tmabpu@hotmail.com, ayesha.aijaz14@gmail.com).

H. Ikram is with the GC University Faisalabad, Pakistan (email: hamidikram@hotmail.com) object could be referred to concrete thing, a topic, a subject-matter, or just as an abstract idea" (pp. 31). The key features of interest include increased attention, concentration and affect. Interest is also responsible for persons' reengagement with specific content such as objects, events and ideas. Since the phenomenon of interest has multifaceted aspects and can be studied and measured at diverse intensities of generalizability with regard to different context, content, and activities [1].

The aim of $21^{\text {st }}$ century is to reconstruct students' interest in the field of science, like chemistry. This could be done by eliminating the factors, which are responsible for declining students' interest towards the courses of chemistry. Students' interest in the curse of chemistry may be affected by different factors. A number of studies have pointed various factors responsible for declining students' interest and attitude toward science. These factors include personal traits [6]: gender [7], grade level [8], type of school, father's occupation [9], age [10], socio-economic status [1], pedagogical aspects [11], audio-visual aids used by the instructors [12], prior learning experiences [13], and career opportunities [11]. These factors may vary from student to student but the differences are more pronounced in different countries [14].

Interest specifies the quality of personal significance. The content taught without relevance to everyday life lead to the lack of interest [5]. The experiments might be a significant tool for the development of more stable interests, which later influence the choices of courses, higher studies, and careers [1]. Students bring curiosity with them when they take their secondary school science courses [1]. The delay or absence of fulfilment of curiosity may lead to decline in interest [14]. It has been reported that male students' liking for chemistry laboratory work declines when they advance towards higher-grade levels [15].

Teaching of science has critical position in the field of education [10]. Teachers' qualification, teaching methodologies, and teaching aids are important aspects for students' learning [16]. Teachers may also influence beliefs of students [17] and their enrolment choices [13], because the early developmental stages of interest require external support. The support from chemistry teacher could help to increase students' interest in chemistry courses [18]. Teachers admire the importance of audio-visual aids in providing assistance for preparing themselves for lecture [19], [20]. But, teachers rarely relate science concepts with everyday life [14]. [21] Researchers argued that one reason for the students' neutral interest in chemistry might be due to chemistry teaching methodologies. Osborne and his co reserchers suggested change in content and teaching style that could significantly increase the interest of students towards physical 
sciences [14]. Osborne and his co-reserchers researcher suggested recruitment of bright enthusiastic teachers of science [14]. The teacher training is necessary to motivate teachers towards profession [4].

Vocational field of learning is one of the important dimensions for developing interest in science students [14], [5]. Educational institutions should help students to choose an educational area where students can better accommodate themselves for future careers [1]. The students mainly prefer their perceptions of science for their career decisions. A small number of students show agreement for choosing STEM (Science, Technology, Engineering and Mathematics) careers due to their intrinsic interest [22], [13]. Students perceive scientific profession as less creative and less people-oriented than other popular fields [14], [23]. Students consider science as useful field for the society but do not consider it useful for future career [21], [24], [25]. Students believe that classroom teaching is the only career opened to the graduates of chemistry [16], [26]. Woodrow (1996) argued that Asian students have a parental impact on their career choices [27]. Nelson et al. (2007) concluded that due to the differences in cognitive abilities of male and female students, the male students are more favourable for high-powered science jobs [28]. The female students indicates that although the discipline of chemistry is necessary for future career, but they do not like to join because they think the field of chemistry is "Hard" for them [29].

The development of interest with a particular scientific object may be for a shorter or longer period of time [1]. The interaction with the interesting scientific object results in the situational interest that is long-term domain specific consequence. Afterward, this situational interest may shift to the high-personalized level of individual interest [5]. Among the age groups, adolescence is the most influential period for the interest development as this period is especially relevant with personal identity and aspiration [30].

Numerous researchers specified the phenomenon of interest with the area of science education [1]. A recent comprehensive attempt for the measurement of students' interest in science courses is made by the Program for International Student Assessment (PISA) 2006. It contributed a lot in opening new sights in the scope of interest evaluation [3].

In Pakistan, concerns have not been raised regarding the interest construct in the field of science education. There is an ample room for efforts with reference to students' interest in science and particularly in the discipline of chemistry.

\section{Methodology}

\section{A. Research Questions}

The present research study answered following three research questions.

1) How much interest do students have in the subject of chemistry at the secondary level?

2) Which factors are responsible for declining students' interest in chemistry at secondary school level?

3) How demographic affected students' interest towards chemistry in secondary school?

\section{B. Research Design}

\section{1) Sample}

The accessible population of the study consisted of secondary school science students (chemistry as one of their science courses) of different school in Lahore, province Punjab, Pakistan. The O-levels chemistry students were not included. This study had a sample size of 600 students chosen through stratified random sampling technique. The further division of the sample is shown in Fig. 1.

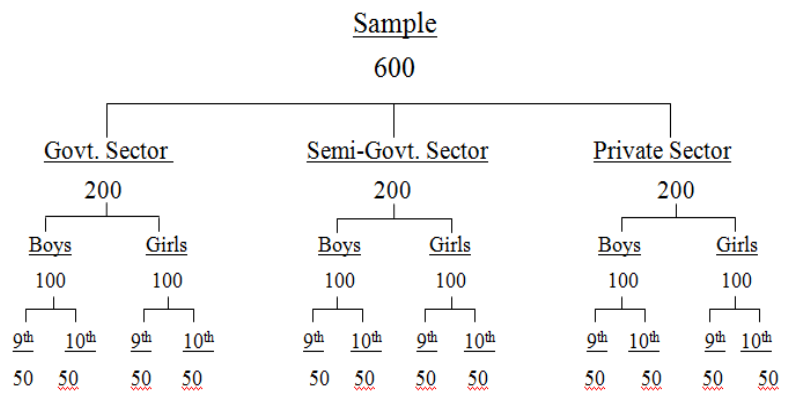

Fig. 1. Categorical division sample.

\section{2) Research instrument}

A questionnaire was developed to collect the close-ended responses from the students. The questionnaire consisted of two sections: one section consisted of demographic variables (gender, class, school name, mother and father occupation, previous and current study major, score percentage and age) and the other section consisted of 31 test items out of which 23 items were positive statements and 8 items were reversed. The test item statements based on the following categories:

1) Existing level of students' interest towards chemistry

2) Personal Choices

3) Role of Teacher

4) Professional Scope

The students were expected to respond by expressing their level of agreement or otherwise on a five-point Likert Scale: Strongly Agree (SA), Agree (A), Undecided (UD), Disagree (D) and Strongly Disagree (SD).

The experts validated the questionnaire. In order to measure the consistency of the questionnaire, a pilot study was conducted on 50 students of $9^{\text {th }}$ and $10^{\text {th }}$ grades. The Cronbach's alpha value was 0.84 .

\section{DATA ANALYSIS AND FINDINGS}

The data was analysed through the mean, standard deviation, percentages, correlation, t-test, and ANOVA.

\section{A. Students' Existing Level of Interest towards Chemistry}

The students' interest towards chemistry was positive but not extraordinary. The students were more interested in chemistry experiments having the highest $(M=4.02, S D=1.15)$. The second highest level of agreement was shown for the statement "I have a lot of questions about chemistry in my mind" $(M=3.76, S D=1.23)$. The students also liked their chemistry classes $(M=3.58, S D=1.32)$ and felt proud being a chemistry student $(M=3.68, S D=1.19)$. The students showed neutral responses for liking the professions based on chemistry discipline $(\mathrm{M}=2.34, \mathrm{SD}=1.29)$. Students perceived 
that jobs for chemistry filed are dry and boring $(M=3.09$, $S D=1.37)$. Furthermore, the students were not interested in research related to chemistry discipline as they had the view that "theories in chemistry cannot be changed or questioned" (Mean=3.34, $S D=1.25$ ) shown in Table I.

A strong positive correlation existed between students' interest towards chemistry and their Personal Choices and perceived The Professional Scope of Chemistry as shown if Fig. 2. There was a weak correlation between students' interest towards chemistry and the Role of Teacher. The gender also weakly correlated with their interest in the subject of chemistry. A weak negative correlation existed between students' interest towards chemistry and their grade level $\left(9^{\text {th }} / 10^{\text {th }}\right)$, school sector (public or private), and age group shown in Fig. 2.

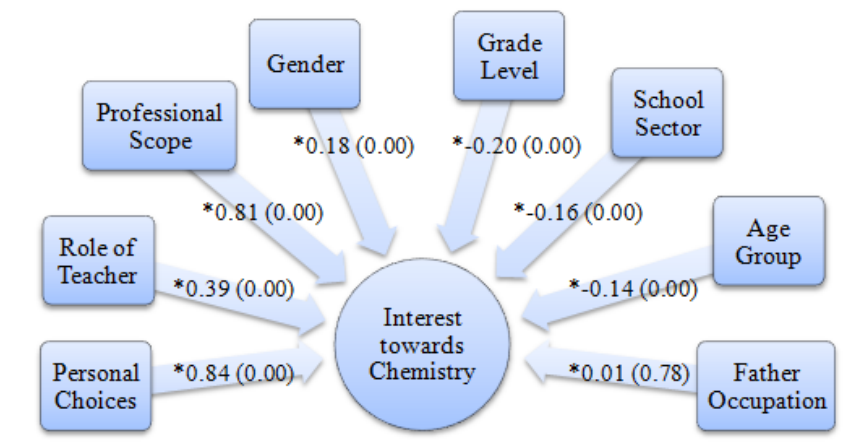

Note: $p \leq 0.01, * r$-value (p-value)

Fig. 2. Pearson correlation coefficient.

TABLE I: ANALYSIS OF FACTOR: STUDENTS' INTEREST TOWARDS CHEMISTRY

\begin{tabular}{|c|c|c|}
\hline $\begin{array}{l}\text { Sr. } \\
\text { No. }\end{array}$ & Existing Level of Interest in Chemistry & $\begin{array}{l}\text { Mean } \\
\text { (S.D) }\end{array}$ \\
\hline 1. & I like my chemistry class. & $\begin{array}{l}3.58 \\
(1.32)\end{array}$ \\
\hline 2. & I will like to have a profession based on chemistry. & $\begin{array}{l}2.34 \\
(1.29)\end{array}$ \\
\hline 3. & $\begin{array}{l}\text { I often discuss about the composition of daily life } \\
\text { materials with my parents. }\end{array}$ & $\begin{array}{l}3.07 \\
(1.30)\end{array}$ \\
\hline 4. & $\begin{array}{l}\text { Only teaching is a profession, which I can join after } \\
\text { learning chemistry. }\end{array}$ & $\begin{array}{l}3.98 \\
(1.04)\end{array}$ \\
\hline 5. & $\begin{array}{l}\text { If I go in higher society, I will feel proud in being a } \\
\text { chemistry student. }\end{array}$ & $\begin{array}{l}3.68 \\
(1.19)\end{array}$ \\
\hline 6. & $\begin{array}{l}\text { Theories in chemistry cannot be changed or } \\
\text { questioned. }\end{array}$ & $\begin{array}{l}3.24 \\
(1.25)\end{array}$ \\
\hline 7. & I enjoy doing chemistry experiments. & $\begin{array}{l}4.02 \\
(1.15)\end{array}$ \\
\hline 8. & $\begin{array}{l}\text { A chemistry-based profession will help me to earn a } \\
\text { handsome salary. }\end{array}$ & $\begin{array}{l}3.30 \\
(1.26)\end{array}$ \\
\hline 9. & I have a lot of questions about chemistry in my mind. & $\begin{array}{l}3.76 \\
(1.23)\end{array}$ \\
\hline 10. & Chemistry oriented jobs are dry and boring. ${ }^{*}$ & $\begin{array}{l}3.09 \\
(1.37)\end{array}$ \\
\hline 11. & $\begin{array}{l}\text { The more I learn in chemistry, the interesting it } \\
\text { becomes. }\end{array}$ & $\begin{array}{l}3.58 \\
(1.32)\end{array}$ \\
\hline 12. & Chemistry has a very limited professional scope. ${ }^{*}$ & $\begin{array}{l}3.03 \\
(1.34)\end{array}$ \\
\hline 13. & $\begin{array}{l}\text { I make an effort to learn chemistry because others } \\
\text { expect it to me. }\end{array}$ & $\begin{array}{l}3.37 \\
(1.34)\end{array}$ \\
\hline
\end{tabular}

*Reverse items

Fig. 3 illustrates that the female students were more interested in chemistry course as compared to male students (For female Mean =3.47, for male Mean =3.26). Similarly the $9^{\text {th }}$ grade students' interest in chemistry course $($ Mean $=3.49)$ was higher than the $10^{\text {th }}$ grade students (Mean =3.25) (Fig. 3). A significant difference existed between the interest level of students belonged to three school sectors (govt., semi-govt. and private). The interest of students in chemistry decreased gradually as move from govt. sector > semi-govt. sector > private sector (Mean values were 3.49, 3.35, and 3.26 respectively) as shown in Fig. 3.

According to Fig. 4, a gradual decrease occurred in students' level of interest towards chemistry with the increase of each 1-year in age group. Among the different occupations of fathers, the children of parents having the profession of technical/vocational services showed the blooming interest. However, the mean values for other professions (govt. job, private job, business, and teacher/engineer/doctor) were almost equal.

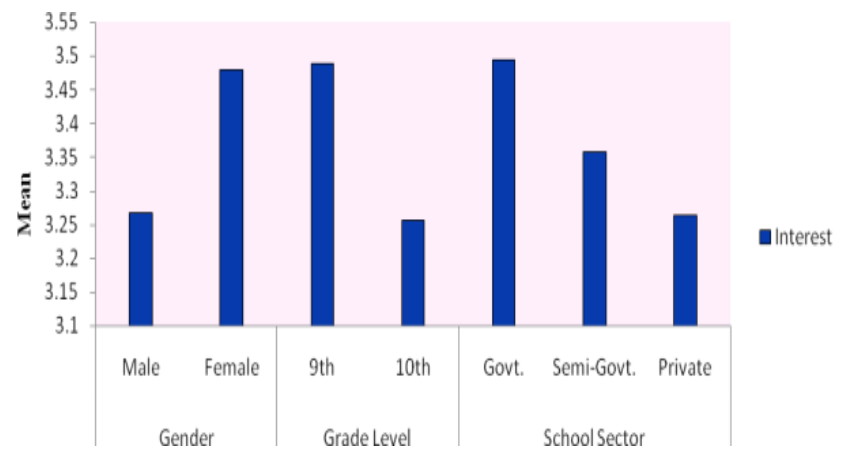

Fig. 3. Comparison between gender, grade level and school sectors.

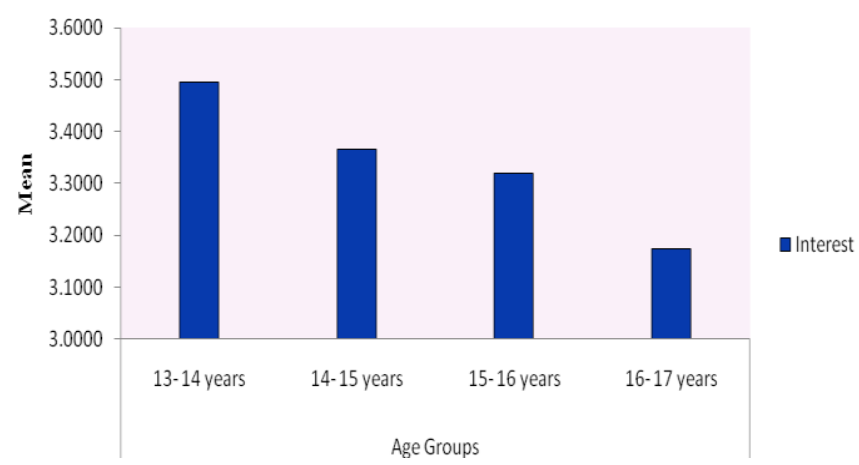

Fig. 4. Comparison between different age groups.

\section{B. Factors Influencing the Interest in Chemistry}

The analysis of the factor Personal Choices showed that students possessed positive attitude towards chemistry. The most prominent feature of students' Personal Choices with regard to chemistry course was their highest level of liking of "chemistry experiments" (Mean=4.02, $S D=1.15)$ and second highest positive response was towards their "curiosity about the course" (Mean=3.76, SD=1.23). The most diminishing feature is their constricted opinion about the scope of research in the field of chemistry (Mean=3.24, $S D=1.26)$. The students liked their chemistry class (Mean=3.58, $S D=1.32$ ) and considered the knowledge of chemistry is useful for routine life (Mean $=3.59, S D=1.15$ ) as shown in Table II.

\section{Performance of Their Chemistry Teachers}

The students were pleased with the Performance of their Chemistry Teachers as the mean values showed strong agreement for the related questionnaire items. According to 
the students, the pedagogical techniques of chemistry teachers were satisfactory (Mean=3.82, $S D=1.33$ ). Teachers used the cross questioning techniques to make their students attentive (Mean=3.44, $S D=1.35$ ). Usually, teachers treated equally to all students in chemistry class (Mean=3.40, $S D=1.34)$. The disagreements about chemistry teachers were as: a) teachers rarely use charts, models, and daily life examples to teach their students (Mean=3.03, $S D=1.43$ ), b) teachers do not assess their students regularly (Mean=3.24, $S D=1.36), \mathrm{c})$ and teachers do not provide extra time to their students (Mean=3.28, $S D=1.42$ ) as shown in Table III.

TABLE II: ANALYSIS OF FACTOR: PERSONAL TRAITS AND CHOICES

\begin{tabular}{clc}
\hline $\begin{array}{c}\text { Sr. } \\
\text { No. }\end{array}$ & \multicolumn{1}{c}{ Personal Traits and Choices } & $\begin{array}{c}\text { Mean } \\
\text { (S.D) }\end{array}$ \\
\hline 1. & I like my chemistry class. & 3.58 \\
& & $(1.32)$ \\
2. & Chemistry is useful for solving everyday problems. & 3.59 \\
& & $(1.15)$ \\
3. $\quad$ Theories in chemistry cannot be changed or & 3.24 \\
& questioned. & $(1.26)$ \\
4. & I enjoy doing chemistry experiments. & 4.02 \\
& & $(1.15)$ \\
5. Ihave a lot of questions about chemistry in my mind. & 3.76 \\
& & $(1.23)$ \\
6. & The more I learn in chemistry, the interesting it & 3.58 \\
& becomes. & $(1.32)$ \\
\hline
\end{tabular}

*Reverse items

TABLE III: ANALYSIS OF FACTOR: ROLE OF TEACHERS

\begin{tabular}{|c|c|c|}
\hline $\begin{array}{l}\text { Sr. } \\
\text { No. }\end{array}$ & Role of Teacher & $\begin{array}{c}\text { Mean } \\
\text { (S.D) }\end{array}$ \\
\hline 1. & $\begin{array}{l}\text { My chemistry teacher use charts, models and daily } \\
\text { life examples to teach us a topic. }\end{array}$ & $3.03(1.43)$ \\
\hline 2. & $\begin{array}{l}\text { In chemistry class, my teacher is good at explaining } \\
\text { things. }\end{array}$ & $3.82(1.33)$ \\
\hline 3. & $\begin{array}{l}\text { My chemistry teacher gives as much attention to me } \\
\text { as to other students. }\end{array}$ & $3.40(1.34)$ \\
\hline 4. & $\begin{array}{l}\text { My teacher also provides extra time to help us } \\
\text { regarding the learning of chemistry. }\end{array}$ & $3.28(1.42)$ \\
\hline 5. & $\begin{array}{l}\text { Teacher does cross questioning during chemistry } \\
\text { lecture. }\end{array}$ & $3.44(1.35)$ \\
\hline 6. & My teacher conduct chemistry tests regularly. & $3.24(1.36)$ \\
\hline
\end{tabular}

\section{The Professional Scope of Chemistry}

The students' responded disagree and strongly disagree towards The Professional Scope of Chemistry.

Firstly, the students had the views that only teaching is a profession that they could join after taking chemistry as a major (Mean=3.98, SD=1.04). Secondly, the students considered the chemistry-based jobs as dry and boring (Mean=3.09, SD=1.37). Thirdly, according to the students, chemistry has a limited professional scope (Mean=3.03, $S D=1.34$ ). Although, the students responded neutrally for the liking of chemistry based professions (Mean=2.34, $S D=1.29$ ) but they considered it popular and a source of handsome salary (Mean $=3.30, S D=1.34$ ) as shown in Table IV.

\section{E. Analysis of the Effect of Demographic Variables on the} Factors
1) The female students showed were more agreed about the factor Personal Choices but there was no significant mean difference male and female students for the liking of their chemistry teacher ( $p$-value >0.05). Similarly, there was no significance mean difference between the views of male and female students about The Scope of Chemistry Subject ( $p$-value $>0.05$ ) as shown in Table V.

TABLE IV: ANALYSIS OF FACTOR PROFESSIONAL SCOPE

\begin{tabular}{|c|c|c|c|c|c|}
\hline $\begin{array}{l}\text { Sr. } \\
\text { No. }\end{array}$ & \multicolumn{4}{|c|}{ Professional Scope } & $\begin{array}{l}\text { Mean } \\
\text { (S.D) }\end{array}$ \\
\hline 1. & \multicolumn{4}{|c|}{ I will like to have a profession based on chemistry. } & $\begin{array}{c}2.34 \\
(1.29)\end{array}$ \\
\hline 2. & \multicolumn{4}{|c|}{$\begin{array}{l}\text { Only teaching is a profession which I can join after } \\
\text { learning chemistry.* }\end{array}$} & $\begin{array}{c}3.98 \\
(1.04)\end{array}$ \\
\hline 3. & \multicolumn{4}{|c|}{$\begin{array}{l}\text { Chemistry oriented jobs are becoming popular day } \\
\text { by day. }\end{array}$} & $\begin{array}{l}3.19 \\
(1.27)\end{array}$ \\
\hline 4. & \multicolumn{4}{|c|}{$\begin{array}{l}\text { A chemistry-based profession will help me to earn a } \\
\text { handsome salary. }\end{array}$} & $\begin{array}{l}3.30 \\
(1.27)\end{array}$ \\
\hline 5. & \multicolumn{4}{|c|}{ Chemistry oriented jobs are dry and boring.* } & $\begin{array}{l}3.09 \\
(1.37)\end{array}$ \\
\hline 6. & \multicolumn{4}{|c|}{ Chemistry has a very limited professional scope.* } & $\begin{array}{r}3.03 \\
(1.34) \\
\end{array}$ \\
\hline \multicolumn{6}{|c|}{ *Reverse items } \\
\hline \multicolumn{6}{|c|}{ TABLE V: EFFECT OF GENDER ON FACTORS } \\
\hline & & Male & Female & & \\
\hline & & $\begin{array}{c}M \\
(\mathrm{SD})\end{array}$ & $\begin{array}{c}M \\
(\mathrm{SD})\end{array}$ & $t$-value & Sign. \\
\hline \multirow{3}{*}{\multicolumn{2}{|c|}{$\begin{array}{l}\text { Personal } \\
\text { Choices } \\
\text { Role of Teacher }\end{array}$}} & 3.50 & 3.75 & -4.19 & 0.00 \\
\hline & & $(0.79)$ & $(0.60)$ & & \\
\hline & & $\begin{array}{l}3.30 \\
(0.89)\end{array}$ & $\begin{array}{l}3.43 \\
(0.86)\end{array}$ & -1.78 & 0.07 \\
\hline \multicolumn{2}{|c|}{$\begin{array}{l}\text { Professional } \\
\text { Scope }\end{array}$} & $\begin{array}{l}3.11 \\
(0.68)\end{array}$ & $\begin{array}{l}3.20 \\
(0.62)\end{array}$ & -1.66 & 0.09 \\
\hline
\end{tabular}

2) The statistically significant mean differences occurred between both grades $\left(9^{\text {th }}\right.$ and $\left.10^{\text {th }}\right)$. The $9^{\text {th }}$ grade students responded positively towards The Personal Choices for Chemistry factor as compared to $10^{\text {th }}$ grade students. The $9^{\text {th }}$ graders were also happy with their teacher than the $10^{\text {th }}$ graders. The $9^{\text {th }}$ graders had less unlikely views than the $10^{\text {th }}$ graders about The Professional Scope of Chemistry as shown in Table VI.

TABLE VI: EFFECT OF GRADE LEVEL ON FACTORS

\begin{tabular}{lcccc}
\hline & $9^{\text {th }}$ Graders & $10^{\text {th }}$ Graders & & \\
& Mean (SD) & $\begin{array}{c}\text { Mean } \\
(\mathrm{SD})\end{array}$ & $t$-value & Sign. \\
\hline Personal Choices & 3.76 & 3.49 & 4.53 & 0.00 \\
& $(0.57)$ & $(0.82)$ & & \\
Role of Teacher & 3.61 & 3.12 & 7.15 & 0.00 \\
Professional & $(0.80)$ & $(0.89)$ & & \\
Scope & 3.30 & 3.01 & 5.57 & 0.00 \\
& $(0.54)$ & $(0.72)$ & & \\
\hline
\end{tabular}

3) The trend for different school sectors (govt., semi-govt. and private) showed that public school students possessed more positive Personal Choices than semi-public school students. The private school students possessed least positive value. The pattern of students' satisfaction with their teachers for different school sectors proved as: private school students > govt. school students > semi-govt. school students. There was no significant difference in the views of students regarding Professional Scope ( $p$-value $>0.05$ ) shown in Table VII. 
TABLE VII: EFFECT OF SCHOOL SECTOR ON FACTORS

\begin{tabular}{lccccc}
\hline \multicolumn{7}{c}{} & $\begin{array}{c}\text { Govt. } \\
\text { Mean } \\
(\text { SD) }\end{array}$ & $\begin{array}{c}\text { Semi-Govt. } \\
\text { Mean } \\
(\text { SD) }\end{array}$ & $\begin{array}{c}\text { Private } \\
\text { Mean } \\
(\text { SD) }\end{array}$ & F-ratio & Sign. \\
\hline Personal & 3.79 & 3.60 & 3.49 & 9.11 & 0.00 \\
Choices & $(0.56)$ & $(0.72)$ & $(0.89)$ & & \\
Role of & 3.41 & 3.19 & 3.50 & 6.65 & 0.00 \\
Teacher & $(0.89)$ & $(0.89)$ & $(0.84)$ & & \\
Professional & 3.22 & 3.12 & 3.11 & 1.67 & 0.18 \\
Scope & $(0.56)$ & $(0.69)$ & $(0.69)$ & & \\
\hline
\end{tabular}

4) Differences in the views of students also existed with regard to the students' age groups. With the increase in age, the students' Personal Choices became less likely for chemistry course. Similarly, the students' level of satisfaction about the performance of chemistry teacher also decreased with increase in students' age. There is no significant difference between age groups for the factor Professional Scope ( $p$-value $>0.05$ ) as shown in Table
VIII.

TABLE VIII: EFFECT OF AGE GROUP ON FACTORS

\begin{tabular}{lcccccc}
\hline Age Group & $\begin{array}{c}13-14 \\
\mathrm{M}\end{array}$ & $\begin{array}{c}14-15 \\
\mathrm{M}\end{array}$ & $\begin{array}{c}15-16 \\
\mathrm{M}\end{array}$ & $\begin{array}{c}16-17 \\
\mathrm{M}\end{array}$ & F-ratio & Sign. \\
\hline $\begin{array}{l}\text { Personal } \\
\text { Choices }\end{array}$ & 3.79 & 3.63 & 3.54 & 3.29 & 6.78 & 0.00 \\
$\begin{array}{l}\text { Role of } \\
\text { Teacher }\end{array}$ & 3.60 & 3.32 & 3.29 & 3.07 & 5.93 & 0.00 \\
$\begin{array}{l}\text { Professional } \\
\text { Scope }\end{array}$ & 3.26 & 3.14 & 3.09 & 3.07 & 2.29 & 0.07 \\
\hline
\end{tabular}

5) The children of parents having technical/vocational jobs had more interest in chemistry with reference to students' Personal Choices and satisfaction for the Performance of Chemistry Teacher but had unlikely views for The Professional Scope of Chemistry as shown in Table IX.

TABLE IX: EFFECT OF FATHER OCCUPATION ON FACTORS

\begin{tabular}{|c|c|c|c|c|c|c|c|}
\hline Father's Profession & Govt. & Private & Business & $\mathrm{T} / \mathrm{V}$ & $\mathrm{T} / \mathrm{E} / \mathrm{D}$ & F- ratio & Sign \\
\hline Personal Choices & 3.65 & 3.59 & 3.59 & 3.88 & 3.59 & 1.86 & 0.11 \\
\hline Role of Teacher & 3.28 & 3.41 & 3.34 & 3.65 & 3.37 & 1.81 & 0.12 \\
\hline Professional Scope & 3.16 & 3.05 & 3.17 & 3.38 & 3.12 & 2.41 & 0.04 \\
\hline
\end{tabular}

\section{DISCUSSION}

The concept of interest had gained new blood in science educational societies [1], [2]. A reason behind is that, students are interested in the "Hard Disciplines" of science like chemistry. Such decline in students' interest is evident in different countries all over the world [1], [14]-[16], [21], [31]-[35]. This present study is also evident that students' interest in chemistry is lower. The most interested aspect that attracted students towards chemistry course was Chemistry Experiments. Osborne and his co-researchers argued that science courses became interesting when they offered with practical opportunities [14]. One reason for more popularity of experimental work is that the students have more control over their educational experiences, and feel ownership while working in laboratories. The experimentation might be significant tool for the development of students' interests, which later influence their choices of courses, higher studies, and careers [1].

The mean value 3.76 for the statement "I have a lot of questions about chemistry in my mind" showed that students are curious about chemistry course. As Krapp and co-researchers (2011) have also mentioned that the students bring curiosity with them when they start their secondary school science [1]. The curiosity helps in developing the students' interest in science courses [26] and teachers can take advantage from students' curiosity [30]. The delay or absence of fulfilment of the requirements of curiosity may decline student's interest [14].

Gender is a key factor in studying students' interest towards science [1]. The present study showed that female students were more interested in chemistry than male students. Conversely, a number of previous researches indicated that male students had more interest than female students in science. Such contradictory findings are evident from different studies [1], [15], [16], [29]. However, research has reported that there is no significant difference in boys and girls regarding the level of interest towards chemistry [21].

There is also a significant difference between $9^{\text {th }}$ and $10^{\text {th }}$ grade students' interest towards chemistry. The $9^{\text {th }}$ grade students were more interested than the $10^{\text {th }}$ grade students. Researchers indicated that male students showed decrease in interest for practical of chemistry with the increase in grade $\left(9^{\text {th }}\right.$ and $\left.10^{\text {th }}\right)$ level [15].

The students' interest towards chemistry decreased when move from govt. school sector > semi-govt. school > private school sector. Authors reported that schools showed better results where students perceived chemistry less difficult [35]. Furthermore reasons might be related to the family income needs and impact of parental occupations. There is a need to explore reasons behind these findings. The students' interest in chemistry subject decreased gradually as the Age of students increased. This decreasing interest in the subject of chemistry with reference to students' age is also an important factor [10]. The students' confidence in their own abilities decreased with the passage of time and students less likely considered subject of chemistry a useful course for them. The factor Personal Choices revealed positive impact on students' interest towards chemistry.

Tytler and his co-reserchers (2006) also reported that the personal characteristics and choices of students were critical in determining students' interest in science [26]. Tytler and his co-reserchers (2006) also mentioned that the students' personal willingness, motivation and cognition are important for the chemistry learning [26]. Those concepts are more interested for students, which have relevance with daily life 
[1].

The teachers are doing well but not best for developing students' interest in chemistry. Their teachers teaching style were satisfactory but they did not use enough charts, models, and daily life examples to enhance students' curiosity and interest. They rarely provided extra time to help students and did not conducted tests regularly. Osborne and his co-researchers (2003) concluded that teachers rarely relate science concepts to everyday life [14]. Salta and his co-workers (2004) argued that students' interest of chemistry course is neutral [21]. One reason for this might be the methods of teaching chemistry. Jegede,(2007) found that the chemistry teachers are a major source of anxiety for students due to the inappropriate teaching styles, lack of encouragement, less use of teaching-aids, and opportunities to manipulate daily life things [16].

The perceived Professional Scope of the chemistry by students strongly correlates with their interest in chemistry course. Hence the Professional Scope has posed negative effect on students' interest. The students were not interested in chemistry-based professions. These results were also evident from different researches [21]. A small number of students showed agreement for having STEM (Science, Technology, Engineering and Mathematics) careers due to their intrinsic interest [22]. This is because of the students' negative perceptions about chemistry-based professions. The present study showed that the students considered the chemistry discipline jobs dry and boring. This unlikely view was much strong that even the handsome salary packages did not attract students towards chemistry related professions. One of the main reasons was that the students were not aware of The Professional Scope of Chemistry discipline. They considered teaching as the only profession, which they will be able to join after completing higher study in the field of chemistry. Jegede (2007) also reported that limited professional scope developed anxiety in chemistry students [16]. The majority of students believed that classroom teaching is the major employment opened to chemistry graduates. Masnick et al. (2010) argued that students mainly preferred their perceptions of science for their career decisions [23]. The students considered scientific professions to be less creative and less people oriented than other popular careers. Osborne and co-workers (2003) also reported that this negative trend might be due to students' perception that science careers are inflexible and have less opportunity for creativity [14]. The reduced level of interest in chemistry-based professions was more pronounced in female students. Such gender inclination is also evident from other studies [16], [29].

\section{CONCLUSION AND IMPLICATIONS}

The present study concluded that the students' interest in chemistry was not high because students had curiosity about the chemistry major. The students were highly interested in doing chemistry experiments but had no interest in chemistry-based professions and in research in the field of chemistry. The female students of $9^{\text {th }}$ grades were more interested than male and 10th grade students. The public school students were more interested while the private school students were least interested in chemistry. Among different father's occupations, the children of parents, related to technical/vocational services, were most interested in chemistry. The students' interest in chemistry decreased gradually increase in students' age.

Among different major factors, Personal Choices played the most critical role in developing students' interest chemistry. The factor, which mainly decline students' interest, was the perception about The Professional Scope of Chemistry. Although teachers were not a major cause for declining students' interest towards chemistry, but students' interest could be enhanced by using appropriate pedagogical techniques.

Student gender had no significant effect on factor Role of Teacher. The father's occupation had no significant impact on Personal Choices and Role of Teacher. Only two demographic variables, grade $\left(9^{\text {th }}\right.$ and $\left.10^{\text {th }}\right)$ level and father occupation had an effect on The Professional Scope of Chemistry perceived by students.

Under the light of the conclusions, it is suggested that the concerns should be raised regarding the measurement of students' interest in different areas of science education. Pakistan should make their way to the international assessments (Like PISA and TIMMS), which include the assessment of interest construct. A special attention must also be paid to the male students whose interest is decreasing in chemistry than female students. The chemistry experiments included in curriculum must be revised to make them more relevant to the theoretical part, presented in textbooks. It might be helpful to develop students' interest in theoretical part. Teachers must be equipped with advanced teaching aids for chemistry teaching. The teachers should regularly assess students on various chemistry concepts and provide feedback. There should be relevant seminars, debates, and field trips for students' encouragement. Educational institutions should conduct aptitude tests to help students to select right courses at right time. Schools should provide career-counselling opportunities to make students aware with the vast scope of science courses in professional fields. Government, commerce, and industrial societies should take solemn action and effectual steps to raise the importance of science related professions. Further researches could be conducted beyond the simplistic explanations to answer the question "why and when interests towards chemistry begin to change?"

\section{REFERENCES}

[1] A. Krapp and M. Prenzel, "Research on interest in science: Theories, methods, and findings," International Journal of Science Education, vol. 33, no. 1, pp. 27-50, 2011.

[2] E. L. Deci and R. M. Ryan, Handbook of Self-determination Research, New York: University of Rochester Press, 2002.

[3] R. V. Olsen and S. Lie, "Profiles of students' interest in science issues around the world: Analysis of data from PISA 2006," International Journal of Science Education, vol. 33, no. 1, pp. 97- 120, 2011.

[4] S. Hidi, "Interest: A unique motivational variable," Educational Research Review, vol. 1, no. 2, pp. 69- 82, 2006.

[5] A. Krapp, "Basic needs and the development of interest and intrinsic motivational orientations," Learning and Instruction, vol. 15, no. 5, pp. 381-395, 2005.

[6] K. Singh, M. Granville, and S. Dika, "Mathematics and science achievement: Effects of motivation, interest, and academic 
engagement," The Journal of Educational Research, vol. 95, no. 6, pp. 323- 332 .

[7] P. Murphy and E. Whitelegg, "Girls and physics: Continuing barriers to 'belonging," Curriculum Journal, vol. 17, no. 3, pp. 281-305, 2006

[8] T. J. Tracey, "Development of interests and competency beliefs: A 1-year longitudinal study of fifth- to Eighth- grade students using the ICA-R and structural equation modeling," Journal of Counseling Psychology, vol. 49, no. 2, pp. 148-163, 2002.

[9] P. Kutnick, "Girls, boys and school achievement critical comments on who achieves in schools and under what economic and social conditions achievement takes place - A Caribbean perspective," International Journal of Educational Development, vol. 20, no. 1, pp. 65-84, 2000.

[10] H. R. Alavi and A. R. Hoseini, "The effect of educational factors on the academic performance of the university students in chemistry," Chemical Education Journal, vol. 13, no. 2, 2009.

[11] T. Semela, "Who is joining physics and why? Factors influencing the choices of physics among Ethiopian university students," International Journal of Environmental and Science Education, vol. 5 , no. 3, pp. 319-340, 2010.

[12] S. Rodrigues, "Factors that influence pupil engagement with science simulations: The role of distraction, vividness, logic, instruction and prior knowledge," Chem. Educ. Res. Pract, vol. 8, no.1, pp.1-12, 2007.

[13] J. Dalgety and R. K. Coll, "The influence of first-year chemistry students' learning experiences on their educational choices,' Assessment and Evaluation in Higher Education, vol. 31, no. 3, pp. 303-328, 2007.

[14] J. Osborne, S. Simon, and S. Collins, "Attitudes towards science: A review of the literature and its implications," International Journal of Science Education, vol. 25, no. 9, pp. 1049-1079, 2003.

[15] D. Cheung, "Students' attitudes toward chemistry lessons: The interaction effect between grade level and gender," Research in Science Education, vol. 39, no. 1, pp. 75-91, 2009.

[16] S. A. Jegede, "Students' anxiety towards the learning of chemistry in some Nigerian secondary schools," Educational Research and Reviews, vol. 2, no. 7, pp. 193-197, 2007.

[17] S. Tobias and J. Raphael, The Hidden Curriculum: Faculty-Made Tests in Science, New York: Plenum, 1997.

[18] A. E. Black and E. L. Deci, "The effects of instructors' autonomy support and students' autonomous motivation on learning organic chemistry: A self-determination theory perspective," Science Education, vol. 84, pp. 740- 756, 2000.

[19] K. S. Taber, "Chemistry lessons for universities?: A review of constructivist ideas," University Chemistry Education: Journal of the Tertiary Education Group of the Royal Society of Chemistry, vol. 4, no. 2, pp. 63-72, 2000

[20] G. M. Mckelvy, "Preparing for the chemistry laboratory: An internet presentation and assessment tool," University Chemistry Education: Journal of the Tertiary Education Group of the Royal Society of Chemistry, vol. 2, no. 1, pp. 46-49, 2000.

[21] K. Salta and C. Tzougraki, "Attitudes toward chemistry among 11th grade students in high schools in greece," Science Education, vol. 88, no. 4, pp. 535-547, 2004.

[22] B. Hannover and U. Kessels, "Self-to-prototype matching as a strategy for making academic choices: Why high school students do not like math and science," Learning and Instruction, vol. 14, pp. 51- 67, 2004.
[23] A. M. Masnick, S. S. Valenti, B. D. Cox, and C. J. Osman, "A multidimensional scaling analysis of students' attitudes about science careers," International Journal of Science Education, vol. 32, no. 5, pp. 653- 667, 2010

[24] M. Bordt, P. DeBroucker, C. Read, S. Harris, and Y. Zhang, "Determinants of science and technology skills: Overview of the study," Education Quarterly Review, Statistic Canada, vol. 8, no. 1, pp. 8-11, 2001.

[25] J. A. Fredricks and J. S. Eccles, "Children's competence and value beliefs from childhood through adolescence: Growth trajectories in two male- sex- typed domains," Developmental Psychology, vol. 38, no. 4, pp. 519-533, 2002.

[26] R. Tytler and D. Symington, "Science in school and society," Teaching Science:The Journal of the Australian Science Teachers Associations, vol. 52, no. 3, pp. 10-15, 2006.

[27] D. Woodrow, "Cultural inclination towards studying mathematics and sciences," New Community, vol. 22, no. 1, pp. 23-38, 1996.

[28] D. J. Nelson and D. C. Rogers, Executive Summary: A National Analysis of Diversity in Science and Engineering Faculties at Research Universitie's, 2007.

[29] A. Cousins, "Gender inclusivity in secondary chemistry: A study of male and female participation in secondary school science," International Journal of Science Education, vol. 29, no. 6, pp. 711-730, 2007.

[30] M. Hofer, "Adolescents' development of individual interests: A product of multiple goal regulation?" Educational Psychologist, vol. 45 , no. 3, pp. 149-166, 2010.

[31] M. G. Jones and M. J. Rua, "Gender difference in students' experiences, interests, and attitudes towards science and scientists," Science Education, vol. 84, no. 2, pp. 180-192, 2000.

[32] G. S. Aikenhead, "Chemistry and physics instruction: Integration, ideologies, and choices," Chemical Education: Research and Practice, vol. 4, no. 2, pp. 115-130, 2003.

[33] T. Lyons, "The puzzle of falling enrolments in physics and chemistry courses: Putting some pieces together," Research in Science Education, vol. 36, no. 3, pp. 285-311, 2006.

[34] P. H. Miller, J. S. Blessing, and S. Schwartz, "Gender differences in high-school students' views about science," International Journal of Science Education, vol. 28, no. 4, pp. 363- 381, 2007.

[35] B. J. Ogunkola and D. Samuel, 'Science teachers' and students' perceived difficult topics in the integrated science curriculum of lower secondary schools in barbados," World Journal of Education, vol. 1, no. 2,2011 .

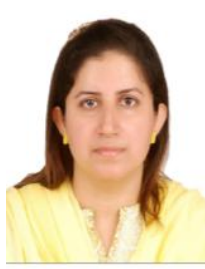

Tayyaba M. Akram was born in Punjab province, Pakistan. She did her bachelor degree (B.Sc.) and the masters of chemistry (M.Sc.) from Lahore College for Women University, Lahore City, Pakistan. She also did the masters degree in science education with major in chemistry and biology teaching from the University of the Punjab, Lahore city, Pakistan. Until now, she is working towards her MPhil leading to $\mathrm{PhD}$ study in the field of environmental sciences, University of the Punjab, Lahore, Pakistan. Her research interests include the chemistry education, science education, environmental education, environmental sciences, comparative science education, science teacher education and educational psychology. 